\title{
Weed Suppression, Nitrogen Availability, and Cabbage Production Following Sunn Hemp or Sorghum-sudangrass
}

\author{
Thierry E. Besançon ${ }^{1}$, Maggie H. Wasacz ${ }^{1}$, and \\ Joseph R. Heckman ${ }^{1}$
}

ADDITIONAL INDEX WORDs. allelopathy, biofumigants, Brassica olevacea, cover crops, Crotalaria juncea, Sorgbum $\times$ drummondi, sustainable agriculture

SuMMARY. Cover crops included in a crop rotation can help increase nitrogen $(\mathrm{N})$ availability to subsequent crops, raise soil organic matter, and suppress emergence and growth of various weed species. However, weed suppression by cover crops has mostly been investigated shortly after cover crop termination and not over a longer period spanning into the next cropping season. The effects of sunn hemp (Crotalaria juncea) and sorghum-sudangrass (Sorghum $\times$ drummondi) planted the previous year on $\mathbf{N}$ availability before transplanting of late summer cabbage (Brassica oleracea), weed germination and growth, and cabbage yield was examined in field studies conducted in 2018 and 2019 at Pittstown, NJ. Results established that there was little evidence for a functional difference in soil $\mathbf{N}$ availability for fall cabbage production because of previous cover crop type. Heavy rainfall events both years may have caused major losses of available $\mathrm{N}$ that might otherwise be expected to come from $\mathrm{N}$ mineralization of residues of legume cover crop like sunn hemp. During the cover crop season, smooth pigweed (Amaranthus bybridus) and common lambsquarters (Chenopodium album) dry biomass was $77 \%$ and $82 \%$ lower, respectively, in sorghum-sudangrass compared with sunn hemp plots. The subsequent season following sorghumsudangrass cover crop, dry biomass of broadleaf weeds was lower by $74 \%$ and $56 \%$ in June and July, respectively, compared with preceding sunn hemp. Smooth pigweed, common lambsquarters, and hairy galinsoga (Galinsoga quadrivadiata) were the weed species most consistently affected by preceding sorghumsudangrass cover crop with biomass decreased by up to $80 \%, 78 \%$, and $64 \%$, respectively. Thus, it appears that sorghum-sudangrass can provide suppression of some broadleaf species over a relatively long period and is indicative of sorghum-sudangrass allelopathic activity. On the contrary, density and biomass of grassy weeds as well as commercial yield of transplanted cabbage were unaffected by the preceding cover crop. These results suggest that sorghumsudangrass cover crop could be integrated to transplanted cole crop rotation for providing weed suppression benefits without altering crop yield in New Jersey organic vegetable cropping systems.

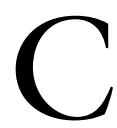
over crops can provide many agronomic services when included in a crop rotation. In general, they may be used to build soil organic matter, feed the soil food web, control soil erosion, capture and prevent nitrate $\left(\mathrm{NO}_{3}\right)$ leaching, provide a habitat for beneficial organisms, and suppress specific crop pests (Bunchek et al., 2018). Growers may specifically select a cover crop for attributes such as biological nitrogen $(\mathrm{N})$ fixation or ability to suppress weeds. Also, the given cover crop must fit within the spatial and seasonal requirements of a crop rotation. Cover crops can aid in weed suppression by actively outcompeting weeds for resources, physically shading the ground to prevent weed seed germination, decreasing the availability of soil $\mathrm{N}$ for weeds, and releasing allelochemicals that may help suppress weeds (Bunchek et al., 2018). However, effectiveness of cover crops is influenced by many factors, such as cover crop species and density, weed species, and timing of cover crop establishment and termination. Cereal grain (Poaceae), legumes ( $\mathrm{Fa}$ baceae), and mustards (Brassicaceae) crops have shown to be beneficial cover crops in vegetables for weed control (Price and Norsworthy, 2013). Using a rye (Secale cereale) cover crop for production of pumpkin (Cucurbita pepo) showed effective weed control without significant loss of yield or crop vigor (Héraux et al., 2005). Additionally, a study by Campiglia et al. (2010) showed that an oat (Avena sativa) cover crop mulch was able to suppress $93 \%$ of aboveground weed biomass in a transplanted tomato ( $\mathrm{So}^{-}$ lanum lycopersicum) system, and a hairy vetch (Vicia villosa) cover crop mulch was able to suppress weeds while yielding $28 \%$ more marketable fruit than in a conventional system.

Sunn hemp (Crotalaria juncea) is a tropical legume cover crop attracting the attention of vegetable growers in the mid-Atlantic United States for its potential to supply $\mathrm{N}$ to rotation crops. Reports suggest that sunn hemp may accumulate as much as $135 \mathrm{~kg} \cdot \mathrm{ha}^{-1} \mathrm{~N}$ via biological $\mathrm{N}$ fixation and produce more than $5600 \mathrm{~kg} \cdot \mathrm{ha}^{-1}$ of dry matter in 9 to 12 weeks (Reeves, 2007). This accumulated $\mathrm{N}$ is held in leaves, stem, and root tissue, each with differing carbon (C)-to- $\mathrm{N}$ ratio and lignin content. The woody stems of mature sunn hemp plants, which may reach up to $1 \mathrm{~cm}$ in diameter, may account for their slow rate of decomposition and residue persistence in soil. Sunn hemp also has allelopathic capabilities, with the candidate allelochemical as delta-

\begin{tabular}{lllc}
\hline $\begin{array}{l}\text { Units } \\
\text { To convert U.S. to SI, } \\
\text { multiply by }\end{array}$ & U.S. unit & SI unit & $\begin{array}{l}\text { To convert SI to U.S., } \\
\text { multiply by }\end{array}$ \\
\hline 0.4047 & acre $(\mathrm{s})$ & $\mathrm{ha}$ & 2.4711 \\
29.5735 & $\mathrm{fl} \mathrm{oz}$ & $\mathrm{mL}$ & 0.0338 \\
0.3048 & $\mathrm{ft}$ & $\mathrm{m}$ & 3.2808 \\
0.0929 & $\mathrm{ft}^{2}$ & $\mathrm{~m}^{2}$ & 10.7639 \\
2.54 & inch $(\mathrm{es})$ & $\mathrm{cm}$ & 0.3937 \\
25.4 & inch $(\mathrm{es})$ & $\mathrm{mm}$ & 0.0394 \\
0.4536 & $\mathrm{lb}$ & $\mathrm{kg}$ & 2.2046 \\
1.1209 & $\mathrm{lb} / \mathrm{acre}$ & $\mathrm{kg} \cdot \mathrm{ha}^{-1}$ & 0.8922 \\
70.0532 & $\mathrm{oz} / \mathrm{acre}$ & $\mathrm{g} \cdot \mathrm{ha}^{-1}$ & 0.0143 \\
305.1517 & $\mathrm{oz} / \mathrm{ft}^{2}$ & $\mathrm{~g} \cdot \mathrm{m}^{-2}$ & 0.0033 \\
7.4892 & $\mathrm{oz} / \mathrm{gal}$ & $\mathrm{g} \cdot \mathrm{L}^{-1}$ & 0.1335 \\
1 & $\mathrm{ppm}$ & $\mathrm{mg} \cdot \mathrm{kg}^{-1}$ & 1 \\
2.2417 & ton $(\mathrm{s}) / \mathrm{acre}$ & $\mathrm{Mg} \cdot \mathrm{ha}^{-1}$ & 0.4461 \\
$\left({ }^{\circ} \mathrm{F}-32\right) \div 1.8$ & ${ }^{\circ} \mathrm{F}$ & ${ }^{\circ} \mathrm{C}$ & $\left({ }^{\circ} \mathrm{C} \times 1.8\right)+32$ \\
& & &
\end{tabular}


hydroxynorleucine (Pilbeam and Bell, 1979). Previous studies have shown that this allelochemical can reduce growth in vegetable species, such as lettuce [Lactuca sativa (Wilson and Bell, 1979)], as well as several weed species. Adler and Chase (2007) showed that sunn hemp ground dried residues reduced germination of goosegrass (Eleusine indica) and livid amaranth (Amar anthus blitum) 3 weeks after planting by $80 \%$ and $61 \%$, respectively, compared with the untreated control. Skinner et al. (2012) demonstrated that sunn hemp ground dried residues were able to inhibit germination and seedling growth of several vegetable and weed species. In the cases of lettuce, turnip (Brassica rapa), and smooth pigweed (Amaranthus hybridus), sunn hemp extracts were more effective at inhibiting germination than rye extracts. Sunn hemp used as a summer cover crop in Florida citrus (Citrus sp.) orchards reduced weed biomass $77 \%$ in comparison with a grass fallow control and provided better weed suppression than alyceclover (Alysicarpus vaginalis) (74\%) and hairy indigo (Indigofera hirsuta) (64\%) cover crops (Linares et al., 2008). Thus, the sunn hemp allelopathy carryover should be considered when selecting it as a cover crop.

Sorghum-sudangrass (Sorghum $\times$ drummondi) is a warm season grass (Poaceae) that grows as tall as sunn hemp and fills the same spatial and temporal niche as a cover crop. Sorghumsudangrass is known for its allelopathic activity that may suppress growth of rotated crops (Weston et al., 1989). Sorgoleone is the major component of sorghum-sudangrass root exudate

Received for publication 21 Jan. 2021. Accepted for publication 9 Apr. 2021.

Published online 6 July 2021.

${ }^{1}$ Department of Plant Biology, School of Environmental and Biological Sciences, Rutgers, The State University of New Jersey, 59 Dudley Road, New Brunswick, NJ 08901-8525

We acknowledge funding support for this research by the Rutgers New Jersey Agricultural Experiment Station. We also express our appreciation for technical support provided by Baylee Carr and Ed Dager.

Mention of trademark, proprietary product, or vendor does not constitute a guarantee or warranty of the product by the authors and does not imply its approval to the exclusion of other products or vendors that also may be suitable.

T.E.B. is the corresponding author. E-mail: thierry.besancon@rutgers.edu.

This is an open access article distributed under the CC BY-NC-ND license (https://creativecommons. org/licenses/by-nc-nd/4.0/).

https://doi.org/10.21273/HORTTECH04811-21 responsible for this crop's herbicidal activity (Czarnota et al., 2001). Extracts from sorghum-sudangrass residues have been shown to significantly reduce the germination of corn (Zea mays), wheat (Triticum aestivum), rice (Oryza sativa), and alfalfa (Medicago sativa) (Chung and Miller, 1995; Kim et al., 1994). Sorghum-sudangrass can also be effective at suppressing many grass and broadleaf weed species. Sorghum mulches applied to apple (Malus $\times$ domestica) orchards were able to suppress smooth crabgrass (Digitaria ciliaris) by $98 \%$ and common purslane (Portulaca oleracea) by $70 \%$ (Putnam et al., 1983). Among many weed species evaluated by Uddin et al. (2009), false cleavers (Galium spurium), redroot pigweed (Amaranthus retroflexus), curly dock (Rumex crispus), and common lambsquarters (Chenopodium album) were the species that showed the highest sensitivity to sorgoleone.

One of the challenges and objectives of green manure management is matching the timing and amount of available $\mathrm{N}$ release with the needs of the following crops. It is especially important to consider if the cover crop is a leguminous or a nonleguminous species as decomposition of the cover crop residues and their management may influence soil $\mathrm{N}$ availability. Thus, objectives of this research were 1) to evaluate the influence of two cover crops on soil $\mathrm{N}$ availability on late summer vegetable production using transplanted cabbage (Brassica oleracea) as a test crop and 2) to compare the population densities and biomass production of selected weed species emerging in the subsequent cabbage crop grown in plots where the cover crops were produced the previous year.

\section{Materials and methods}

Field experiments were conducted on two fields in 2017 and 2018 at the Rutgers University Snyder Research and Extension Farm near Pittstown, NJ. Both fields were Quakertown silt loam soil (fine-loamy, mixed, mesic Typic Hapludult). Cover crops sorghum-sudangrass and sunn hemp (Johnston Seed Co., Enid, OK) were grown 1 year in advance of a crop rotation to fall cabbage as a way to condition the soil for weed suppression and build soil fertility. The individual sorghum-sudangrass and sunn hemp cover crop plots ( $10 \mathrm{ft}$ wide by $30 \mathrm{ft}$ long) were seeded on 2 June 2016 and 14
June 2017 using grain drill with a row spacing of 7 inches. The seeding rates were $4 \mathrm{lb} /$ acre for sorghum-sudangrass and $35 \mathrm{lb} /$ acre for sunn hemp. Before planting the cover crops the soil seedbed was prepared by using a disc and a rotary tiller. The previous crop before seeding the cover crops was mixed grass sod in 2015 and field corn harvested for grain in 2016. Each year after a killing frost, cover crops were mowed down to a 6-inch stubble with cover crop residue allowed to blanket or mulch the soil in the plots over the winter months. Dry residues of cover crop plots were tilled on 4 May 2017 and 10 May 2018 using a disc to lightly incorporate the cover crop residue. Since the study was originally designed to evaluate the carryover effects of sunn hemp and sorghum-sudangrass cover crops on soil $\mathrm{N}$ availability, a control without cover crop was not included in the study design. A 7-ft-wide strip of sod was maintained as a buffer between individual cover crop plots and was mowed as needed.

Nitrogen MONITORING. Soil samples were taken by collecting four cores $(2 \mathrm{~cm}$ diameter $\times 30 \mathrm{~cm}$ deep) from plots left unplanted with cabbage every $14 \mathrm{~d}$ from 19 May to 20 Oct. 2017, and from 10 May to 25 Oct. 2018. Shallow ( 1 inch deep) cultivation was occasionally performed to keep these unplanted plots weed free. Presidedress soil nitrate test (PSNT) soil samples were also taken at $\approx 2$ weeks after transplanting on 11 Aug. 2017 and 16 Aug. 2018 from the plots planted with cabbage by using this same soil sampling procedure as previously described. After collection, the soil cores were composited by plot and immediately spread in a thin layer (0.5 inch thick) to dry in metal pans placed on bench in a warm space to air dry for $24 \mathrm{~h}$. The dry soil was crushed to pass a $2-\mathrm{mm}$ screen and was thoroughly mixed. Five cubic centimeters of dried and sieved soil were scooped and mixed to $25 \mathrm{~mL}$ of $0.5 \mathrm{~m}$ sodium chloride $(\mathrm{NaCl})$ extractant for a soil:solution ratio of $1: 5$. The solution was shaken in $60-\mathrm{mL}$ glass bottles with rubber stoppers in a reciprocating shaker at 180 oscillations per minute for $30 \mathrm{~min}$. Samples were poured into funnels and filtered into polypropylene scintillation vials. The filtrate was then poured off into 4-mL vials to load onto an auto- 
analyzer (AutoAnalyzer 3 with AACE software; SEAL Analytical, Mequon, WI). The sample extract was pumped into the chemistry manifold of the auto-analyzer, which adds and mixes the reagents in proper proportions according to the method recommended by Griffin et al. (1995). $\mathrm{NO}_{3}$ and ammonium $\left(\mathrm{NH}_{4}\right)$ were analyzed in separate runs of the auto-analyzer. $\mathrm{NO}_{3}$ and $\mathrm{NH}_{4}$ concentration in the extract was based on color intensity using a digital colorimeter fitted with a 550$\mathrm{nm}$ filter for $\mathrm{NO}_{3}$ and a 660-nm filter for $\mathrm{NH}_{4}$ detection, respectively. Concentration was evaluated by comparison with standard calibration curves.

WeEd infestation. In Spring 2017 , visual differences in weed growth were noted between plots depending on the type of cover crop grown the preceding year. Therefore, it was decided to include an evaluation of sorghumsudangrass and sunn hemp impact on weeds to the original soil $\mathrm{N}$ availability study. Weed density and biomass were evaluated in plots left unplanted and undisturbed the year following the establishment and subsequent mowing of cover crops. The statistical design for evaluating weed infestation was a randomized complete block with five replications, and the experiment was repeated over the course of 2 years. Weeds were counted and collected within a 2.25 -ft-square area randomly selected in the center of each plot and delineated by using a square plastic frame. Two subsamples were collected from each plot at each rating date with collection occurring on 14 June 2017 and 2018; 12 July 2017 and 19 July 2018; 9 Aug. 2017 and 14 Aug. 2018. All samples were placed into paper bags and dried at $65^{\circ} \mathrm{C}$ for $96 \mathrm{~h}$ for dry biomass weighing. A similar protocol was used to evaluate density and biomass of cover crops and weeds growing under the cover crop canopy before termination of the cover crops. This evaluation was conducted on 27 Oct. 2017 but not in 2016 because this project was not initially focused on evaluating the interactions between weeds and preceding cover crops.

Cabbage maintenance and HARVESTING. In preparation of cabbage transplanting, plots were rototilled twice on 13 and 20 July 2017, and 19 and 30 July 2018. 'Benelli' cabbage (Seedway, Hall, NY) seedlings were greenhouse grown for about 5 weeks. While in the greenhouse, plants received a weekly application of a watersoluble fertilizer, prepared by mixing 3 $\mathrm{g} \cdot \mathrm{L}^{-1}$ of $15 \mathrm{~N}-13 \mathrm{P}-12.5 \mathrm{~K}$ soluble fertilizer (Jack's Pro; JR Peters, Allentown, PA) of water and applying $27 \mathrm{~mL}$ of solution per plant. Cabbage seedlings were transplanted on 28 July 2017 and 31 July 2018. At each experimental site, cabbage transplants were spaced 14 inches apart within the rows and 30 inches between rows to establish populations of 14,930 plants/acre. Irrigation was applied after transplanting and as needed during the cabbage growing season. At time of transplanting, $100 \mathrm{~mL}$ of a $15 \mathrm{~N}-13 \mathrm{P}-12.5 \mathrm{~K}$ fertilizer solution was applied to the field soil beside each transplant. Phosphorus, potassium, sulfur, and boron fertilizers were broadcast at the commercially recommended rate based on a recent soil fertility test and incorporated with tillage. Within each plot, weeds were kept under control by regular hand weeding and hoeing. Insect control was achieved by applying $2.4 \mathrm{oz} /$ acre spinosad (Entrust; Dow AgroSciences, Indianapolis, IN) three to four times during the cropping season.

Cabbage heads were harvested on 27 Oct. 2017 and 25 Oct. 2018. Twenty heads from the center two rows of each of the four row plots were cut aboveground level with a knife. All heads were rated as being of marketable size (U.S. No. 1) according to the U.S. Department of Agriculture, Agricultural Marketing Service (2016) standards for grading of cabbage. Cabbage yield per plot was measured by weighing the collection of the 20 heads as an experimental unit.

Statistical analysis. Years, cover crop, and all interactions containing these two factors were consid ered fixed effects, whereas replications (nested within years) were considered random effects (Carmer et al., 1989). Weed infestation and cabbage yield data were subjected to a two-way analysis of variance using the generalized linear mixed model (GLIMMIX) proc edure in SAS (version 9.4; SAS Institute, Cary, NC) to determine if years could be combined for regression analysis. Mean comparisons between the two cover crops were performed using Fisher's protected least significant difference test when $F$ values were statistically significant $(P \leq 0.05)$. A paired $t$-test was performed on the NO3,
$\mathrm{NH} 4$, and total $\mathrm{N}$ soil concentrations data using PROC TTEST in SAS to determine whether there was a significant difference $(P \leq 0.05)$ in the means for each sampling date within each year.

\section{Results and discussion}

DyNAMIC OF SOIL NITROGEN. Temporal concentrations of mineral $\mathrm{N}$ in the upper 12 inches of soil exhibited changes from May to October in the unplanted fallow plots (Fig. 1). These patterns are roughly similar to hypothetical accumulation of mineralized $\mathrm{N}$ in warm moist soil in the absence of crop $\mathrm{N}$ uptake (Magdoff, 1991). $\mathrm{NH}_{4}$ concentration levels were generally less than 5 ppm and declined to very low levels from May to October as may be expected because the process of nitrification proceeds rapidly in warm soil (Fig. $1 \mathrm{~A}$ and $\mathrm{B}$ ). $\mathrm{NO}_{3}$ concentration levels generally increased since no growing plants were present to absorb this nutrient (Fig. $\mathrm{IC}$ and $\mathrm{D})$. Fallow plots previously cover cropped with sunn hemp tended to have higher levels of available mineral $\mathrm{N}$ in soil compared with sorghum-sudangrass, but the differences were statistically significant in only a few instances (Fig. IE and F).

Precipitation in July 2017 and 2018 exceeded the 30-year average by $30 \mathrm{~mm}$ (Fig. 2) and likely caused some loss of $\mathrm{NO}_{3}$ from soil via leaching and denitrification. In both growing seasons and for both cover crop types, soil sampling and soil $\mathrm{NO}_{3}$ testing at $\approx 2$ weeks after cabbage transplanting found $\mathrm{NO}_{3}$ levels near the 10-ppm level. On the basis of soil test calibration research with cabbage (Heckman et al., 2002), which identified 25 ppm as the critical level, the PSNT results in 2017 and 2018 predicted that supplemental $\mathrm{N}$ fertilizer was needed for all plots. Also, based on PSNT results there was no indication for needing to adjust the $\mathrm{N}$ application rates based on the type of cover crop that proceeded cabbage. Although a legume cover crop such as sunn hemp may be expected to biologically fix significant amounts of $\mathrm{N}$, which should be well timed for mineralization and utilization by a fall crop, there was little evidence for a functional difference in soil $\mathrm{N}$ availability for fall cabbage production because of previous cover crop type. In both years, heavy rainfall 


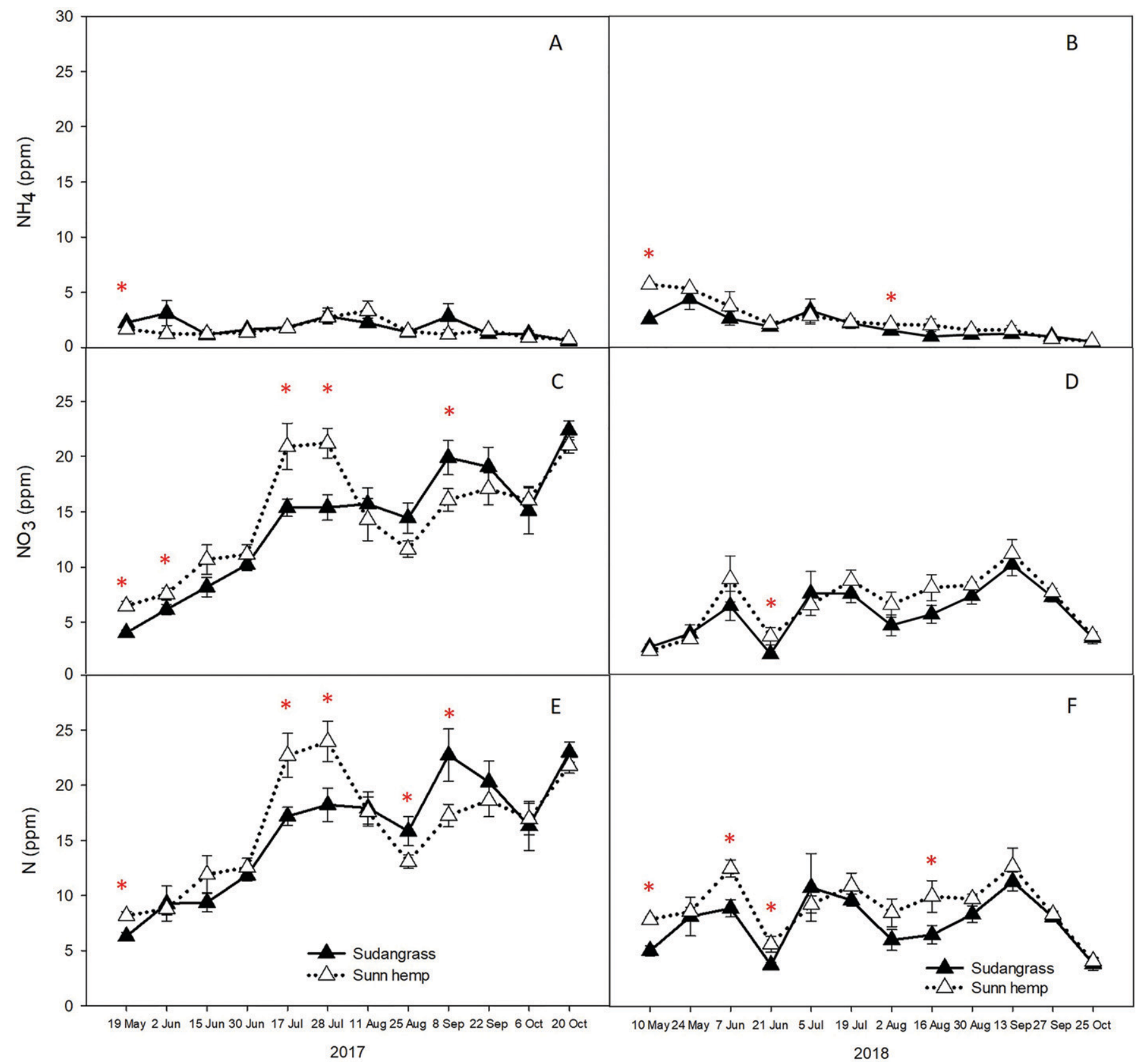

Fig. 1. Ammonium $\left[\mathrm{NH}_{4}(\mathrm{~A}\right.$ and $\left.\mathrm{B})\right]$, nitrate $\left[\mathrm{NO}_{3}(\mathrm{C}\right.$ and $\left.\mathrm{D})\right]$, and total nitrogen $[\mathrm{N}(\mathrm{E}$ and $\mathrm{F})]$ concentration in the surface 30 $\mathrm{cm}$ (11.8 inches) of soil from soil sampling every $14 \mathrm{~d}$ between May and October in 2017-18 at Rutgers Snyder Research and Extension Farm, Pittstown, NJ. Within year, red asterisks indicate significant difference in $\mathrm{NH}_{4}, \mathrm{NO}_{3}$, or total $\mathrm{N}_{\text {concentration }}$ between the two cover crop treatments at that data (two-tailed paired $t$ test at $P \leq 0.05$ ); $1 \mathrm{ppm}=1 \mathrm{mg} \cdot \mathrm{kg}^{-1}$.

events may have caused major losses of available $\mathrm{N}$ that might otherwise be expected to come from $\mathrm{N}$ mineralization of legume cover crop residue.

WEED SUPPRESSION DURING COVER CROPPING. Data collected in Oct. 2017 showed that sunn hemp produced 13.1 $\mathrm{Mg} \cdot \mathrm{ha}^{-1}$ of dry biomass for a density of 19,400 plants/acre whereas sorghumsudangrass only produced $5.5 \mathrm{Mg} \cdot \mathrm{ha}^{-1}$ of dry biomass at a 43,700 plants/acre density. Lower dry biomass production observed for sorghum-sudangrass may be the result of the lack of fertilization before seeding of the cover crop but could also be caused by a low seeding rate compared with previous research. For example, Wang et al. (2008) reported a sorghum-sudangrass dry biomass production of $8 \mathrm{Mg} \cdot \mathrm{ha}^{-1}$ at a seeding rate 3 times higher than the one used in the present study.

Sampling of weeds growing under the cover crop canopy indicated that common lambsquarters, hairy galinsoga (Galinsoga quadriradiata), smooth pigweed, and large crabgrass (Digitaria sanguinalis) combined were accounting for $93 \%$ and $98 \%$ of total weed density and dry biomass, respectively. Cover crop species did not influence large crabgrass density or biomass production (Table 1). Cover crops had a more significant influence on smooth pigweed and common lambsquarters, the biomass of which was $82 \%$ lower 


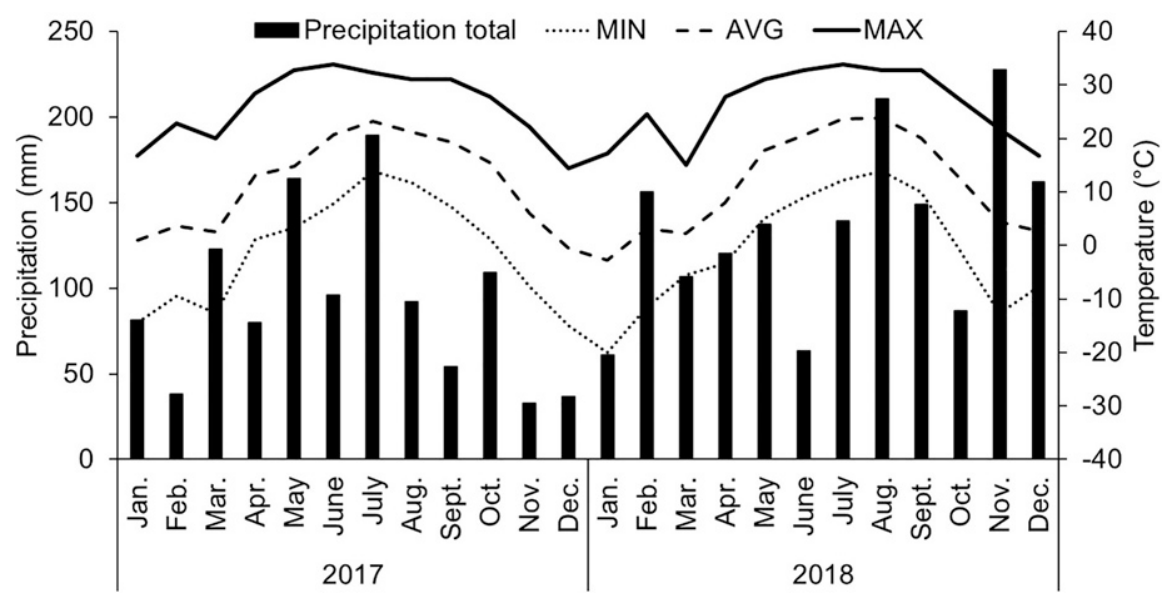

Fig. 2. Precipitation and daily minimum (MIN), maximum (MAX), and mean (AVG) air temperature records by month in 2017-18 at Rutgers Snyder Research and Extension Farm, Pittstown, NJ; $1 \mathrm{~mm}=0.0394$ inch, $\left(1.8 \times{ }^{\circ} \mathrm{C}\right)+32={ }^{\circ} \mathrm{F}$.

with sorghum-sudangrass compared with sunn hemp. Hairy galinsoga biomass was unaffected by the type of cover crop, but its emergence was $89 \%$ lower in sunn hemp compared with sorghum sudangrass. Lower emergence of hairy galinsoga was likely attributable to its semierect growth habit that can make it more sensitive to competition from dense canopy crop compared with more erect plants such as common lambsquarters or smooth pigweed. Previous research on the suppressive effect of cover crops on hairy galinsoga have shown a $90 \%$ reduction of hairy galinsoga emergence (compared with a weedy check) in oat cover crop producing 9.6 $\mathrm{Mg} \cdot \mathrm{ha}^{-1}$ of dry biomass vs. $30 \%$ emergence reduction in a yellow mustard (Sinapsis alba) cover crop that produced significantly less biomass with $6.8 \mathrm{Mg} \cdot \mathrm{ha}^{-1}$ (Kumar et al., 2009).

WEED SUPPRESSION AFTER COVER CroppING. The season following cover cropping, four monocotyledonous and
23 dicotyledonous weed species were recorded in the quadrats over the course of the 2 years. However, only eight species consistently noted across repetitions and years were specifically analyzed and discussed. They consisted of carpetweed (Mollugo verticillata), large crabgrass, mouseear chickweed (Cerastium fontanum), dandelion (Taraxacum officinale), common lambsquarters, hairy galinsoga, pennsylvania smartweed (Persicaria pensylvanica), and smooth pigweed. The four last species of the list are ranked among the 10 most troublesome weed species for vegetable production in the mid-Atlantic United States (Van Wychem, 2019). The two-way interaction of preceding cover crop by year was not significant $(P>0.05)$ for weed density, weed biomass, and cabbage yield. Thus, corresponding data were pooled across years.

Broadleaf Weeds. Following sorghum-sudangrass cover cropping the previous year, the dry biomass and

Table 1. Weed density and dry biomass in October as affected by season-long sorghum-sudangrass or sunn hemp cover cropping in 2017 at Rutgers Snyder Research and Extension Farm, Pittstown, NJ.

\begin{tabular}{lcccc}
\hline & GASCI & CHEAL & AMACH & DIGSA \\
\cline { 2 - 5 } Cover crop & \multicolumn{4}{c}{ Weed density $\left(\text { plants } / \mathbf{m}^{2}\right)^{\mathbf{z}}$} \\
\hline Sorghum-sudangrass & $27 \mathrm{a}^{\mathrm{y}}$ & 56 & 10 & 41 \\
Sunn hemp & $3 \mathrm{~b}$ & 77 & 11 & 24 \\
& & Weed dry biomass $\left(\mathbf{g} \cdot \mathbf{m}^{-2}\right)$ & \\
Sorghum-sudangrass & 1.8 & $3.7 \mathrm{~b}$ & $1.4 \mathrm{~b}$ & 20.6 \\
Sunn hemp & 1.5 & $20.1 \mathrm{a}$ & $8.2 \mathrm{a}$ & 22.7 \\
\hline
\end{tabular}

${ }^{\mathrm{z}} \mathrm{l}$ plant $/ \mathrm{m}^{2}=0.0929$ plant $/ \mathrm{ft}^{2}, \mathrm{l} \mathrm{g} \cdot \mathrm{m}^{-2}=0.0033 \mathrm{oz} / \mathrm{ft}^{2}$.

${ }^{y}$ Means within a column followed by different letters are significantly different (Fisher's protected least significant difference test at $P \leq 0.05$ ).

GASCI $=$ hairy galinsoga; $\mathrm{CHEAL}=$ common lambsquarters; $\mathrm{AMACH}=$ smooth pigweed DIGSA $=$ large crabgrass. density of broadleaf weed seedlings in June was lowered by $74 \%$ and $41 \%$ compared with a sunn hemp cover crop (Fig. 3A and C). No significant difference of weed density was observed in July, whereas weed dry biomass was still $56 \%$ lower in plots cover cropped with sorghum-sudangrass compared with sunn hemp. Tillage of the plots in late July in preparation of cabbage transplanting killed established plants but stimulated the emergence of new dicotyledonous seedlings as shown by the doubling of emerged seedlings counted in August compared with July for both preceding cover crops. However, the number of weed seedlings was again lower by $38 \%$ in plots that had sorghum-sudangrass cover crop the previous year compared with sunn hemp. The excessive precipitation mentioned previously also likely caused $\mathrm{NO}_{3}$ loss through leaching and contributed to the lack of significant difference for broadleaf weed biomass in August between the two cover cropping systems. It is possible that higher weed germination in sunn hemp plots in August may have been stimulated by higher midsummer $\mathrm{NO}_{3}$ concentration associated with this cover crop as observed in 2017 (Fig. 1).

Previous research has shown that emergence of broadleaf weeds such as common lambsquarters or ladysthumb (Polygonum persicaria) can increase with increasing availability of soil N (Sweeney et al., 2008). Yet a similar effect was noted in 2018 when $\mathrm{NO}_{3}$ concentration was not different between the two cover-cropping systems. Thus, it is possible that carryover of sorghum-mediated allelopathy may have influenced the emergence and development of broadleaf weeds the year following cover crops. Similarly, Einhellig and Rasmussen (1989) reported an inhibitory activity of grain sorghum (Sorghum bicolor) crop the following year on early season broadleaf weeds abundance and midsummer weed biomass compared with soybean (Glycine max) or corn crop. This was attributed to the collective action of several allelopathic compounds released by grain sorghum either through root exudation or decomposition of crop residues. Wortman et al. (2014) noted that decomposition of shoot residues and root exudates of sorghum-sudangrass had synergistic effect on green foxtail (Setaria viridis) seeded immediately 


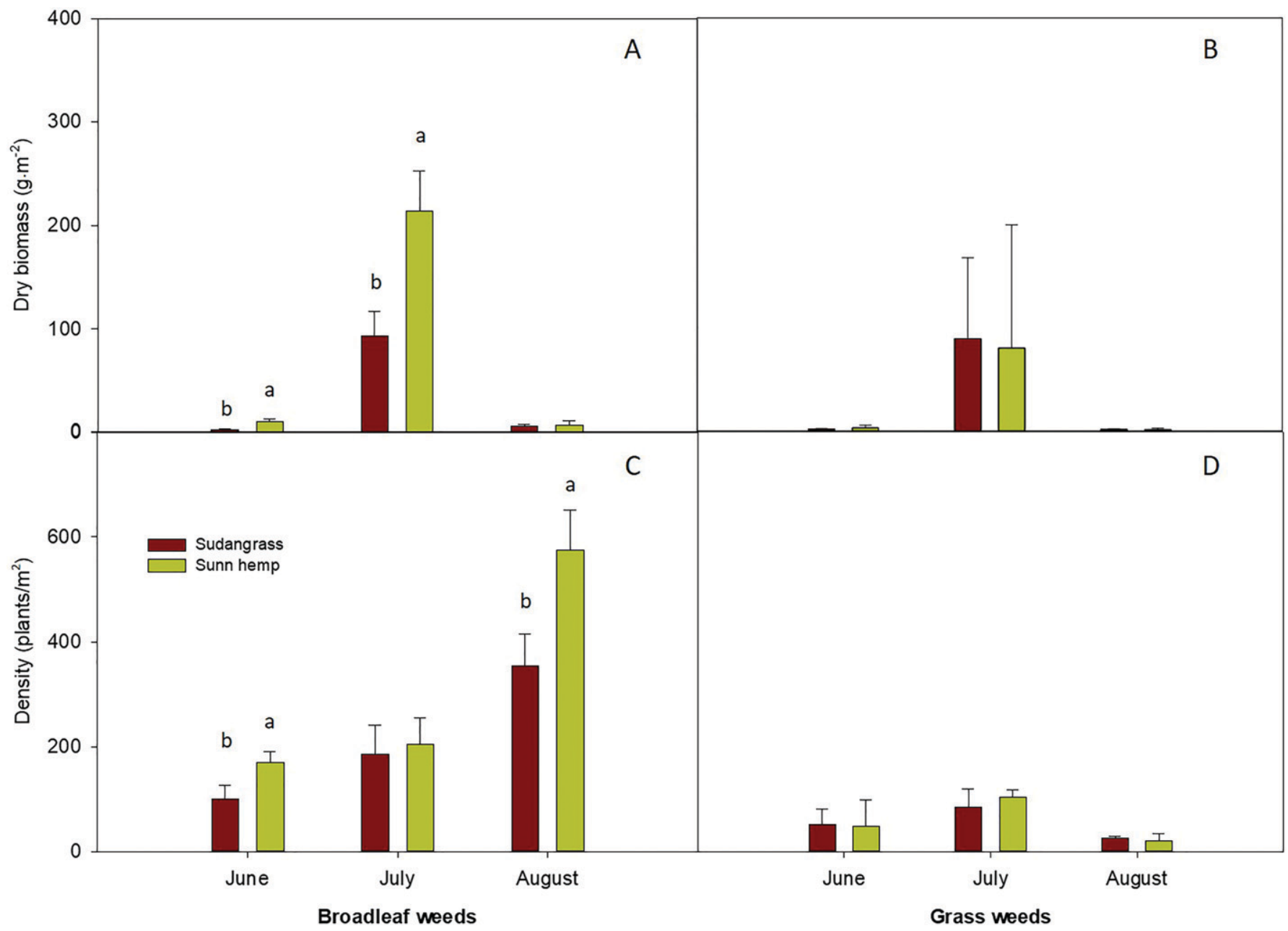

Fig. 3. Total dry biomass and density for broadleaf (A and C, respectively) and grass (B and D, respectively) weeds at three sampling dates following sorghum-sudangrass or sunn hemp cover cropping the previous season in 2017-18 at Rutgers Snyder Research and Extension Farm, Pittstown, NJ. Data were pooled across years and means within a figure and a month followed by different letters are significantly different (Fisher's protected least significant difference test at $P \leq 0.05$ ); 1 $\mathrm{g} \cdot \mathrm{m}^{-2}=0.0033 \mathrm{oz} / \mathrm{ft}^{2}, 1$ plant $/ \mathrm{m}^{2}=0.0929 \mathrm{plant} / \mathrm{ft}^{2}$.

after sorghum-sudangrass termination by 4 to $12 \mathrm{~d}$, depending on soil organic matter content, compared with a soil without sorghum-sudangrass residues or root exudates.

A detailed analysis by species for the dominant weeds in June indicated no significant effect of preceding cover crops on the density of early summer emerging species (galinsoga and lambsquarters) as well as on more perennial species (dandelion and mouseear chickweed) seedlings whereas the dry biomass of these species decreased $53 \%$ to $80 \%$ in plots planted with sorghum-sudangrass the previous year compared with sunn hemp (Table 2).

The lack of significant effect of preceding cover crop species on galinsoga, common lambsquarters, dandelion, and mouseear chickweed density was again noted in July (Table 3 ). Regarding the dry biomass of these four species, only common lambsquarters and hairy galinsoga were significantly affected with a $78 \%$ and $50 \%$ biomass reduction, respectively, for plants emerging from plots with sorghum-sudangrass as the preceding cover crop compared with sunn hemp. Smooth pigweed and pennsylvania smartweed were detected for the first time in July and both were significantly affected by the preceding cover crop. Pennsylvania smartweed and smooth pigweed density was $77 \%$ lower and dry biomass by $72 \%$ to $78 \%$ lower following sorghum-sudangrass cover crop compared with sunn hemp.

The cultivation of the plots that preceded the transplanting of cabbage eliminated most of the emerged weeds and stimulated the emergence of new seedlings as illustrated by decreased weed biomass and increased weed density counts in August compared with July (Table 4). A late summer annual weed, carpetweed, was added to list of species analyzed in August. Except for smooth pigweed (reduction by $58 \%$ ) and carpetweed (reduction by $37 \%$ ), density of the major weed species counted in August was not significantly affected by preceding sorghum-sudangrass compared with sunn hemp. Aboveground biomass produced by hairy galinsoga, common lambsquarters and smooth pigweed was again lower with sorghum-sudangrass preceding cover crop compared with sunn hemp with dry weight reduction by $63 \%$, $50 \%$, and $67 \%$, respectively.

Overall, our data show that sorghum-sudangrass cover crop may inhibit the germination and growth of some broadleaf weeds up to 10 months after termination compared with a sunn 
Table 2. Broadleaf weeds density and dry biomass in June as influenced by sorghum-sudangrass or sunn hemp cover cropping the preceding season in 2017-18 at Rutgers Snyder Research and Extension Farm, Pittstown, NJ.

\begin{tabular}{lcccc}
\hline & GASCI & CHEAL & TAROF & CERVU \\
\cline { 2 - 5 } Cover crop & \multicolumn{4}{c}{ Weed density $\left(\text { plants } / \mathbf{m}^{2}\right)^{\mathbf{z}}$} \\
\hline Sorghum-sudangrass & 9 & 4 & 2 & 3 \\
Sunn hemp & 14 & 9 & 4 & 5 \\
& & Weed dry biomass $\left(\mathrm{g} \cdot \mathbf{m}^{-2}\right)$ & \\
Sorghum-sudangrass & $0.8 \mathrm{~b}^{\mathrm{y}}$ & $0.3 \mathrm{~b}$ & $0.1 \mathrm{~b}$ & $0.3 \mathrm{~b}$ \\
Sunn hemp & $1.7 \mathrm{a}$ & $0.7 \mathrm{a}$ & $0.5 \mathrm{a}$ & $1.0 \mathrm{a}$ \\
\hline
\end{tabular}

${ }^{\mathrm{z}} 1$ plant $/ \mathrm{m}^{2}=0.0929$ plant $/ \mathrm{ft}^{2}, \mathrm{lg} \cdot \mathrm{m}^{-2}=0.0033 \mathrm{oz} / \mathrm{ft}^{2}$.

${ }^{y}$ Data were pooled across years and means within a column followed by different letters are significantly different (Fisher's protected least significant difference test at $P \leq 0.05$ )

GASCI = hairy galinsoga; $\mathrm{CHEAL}=$ common lambsquarters; $\mathrm{TAROF}=$ dandelion; $\mathrm{CERVU}=$ mouseear chickweed.

Table 3. Broadleaf weeds density and dry biomass in July as influenced by sorghum-sudangrass or sunn hemp cover cropping the preceding season in 2017-18 at Rutgers Snyder Research and Extension Farm, Pittstown, NJ.

\begin{tabular}{llrcccc}
\hline & GASCI & CHEAL & TAROF & CERVU & AMACH & POLPY \\
\cline { 2 - 7 } Cover crop & \multicolumn{7}{c}{ Weed density $\left(\text { plants } / \mathbf{m}^{2}\right)^{\mathbf{z}}$} \\
\hline Sorghum-sudangrass & 10 & 9 & 10 & 0.3 & $7 \mathrm{~b}^{\mathrm{y}}$ & $0.6 \mathrm{~b}$ \\
Sunn hemp & 11 & 12 & 7 & 0.2 & $31 \mathrm{a}$ & $2.6 \mathrm{a}$ \\
& \multicolumn{7}{c}{ Weed dry biomass $\left(\mathrm{g} \cdot \mathrm{m}^{-2}\right)$} \\
Sorghum-sudangrass & $4.4 \mathrm{~b}$ & $6.8 \mathrm{~b}$ & 2.9 & 0.2 & $4.3 \mathrm{~b}$ & $1.9 \mathrm{~b}$ \\
Sunn hemp & $8.8 \mathrm{a}$ & $31.6 \mathrm{a}$ & 2.2 & 0.2 & $19.7 \mathrm{a}$ & $6.7 \mathrm{a}$ \\
\hline
\end{tabular}

${ }^{\mathrm{z}} 1$ plant $/ \mathrm{m}^{2}=0.0929 \mathrm{plant} / \mathrm{ft}^{2}, \mathrm{l} \mathrm{g} \cdot \mathrm{m}^{-2}=0.0033 \mathrm{oz} / \mathrm{ft}^{2}$.

${ }^{\mathrm{y}}$ Data were pooled across years and means within a column followed by different letters are significantly different (Fisher's protected least significant difference test at $P \leq 0.05$ ).

GASCI = hairy galinsoga; $\mathrm{CHEAL}=$ common lambsquarters; TAROF $=$ dandelion; $\mathrm{CERVU}=$ mouseear chickweed; AMACH = smooth pigweed; POLPY = pennsylvania smartweed.

hemp cover crop. However, because this study lacks a proper control without preceding cover crop, it is not possible to determine the inhibitory activity of sunn hemp cover crop on emergence and growth of subsequent weeds.

Grass weEDs. Cumulative weed density and dry biomass of grass weed species was not significantly affected

by the cover crop species grown the previous year for any of the three rating dates (Fig. 3B and D). Large crabgrass was by far the predominant grass species and was unaffected by preceding cover crops at any rating date. Previous studies have reported minimal activity of sunn hemp aqueous foliar extract on germination of goosegrass, sweet corn,

Table 4. Broadleaf weeds density and dry biomass in August as influenced by sorghum-sudangrass or sunn hemp cover cropping the preceding season in 2017-18 at Rutgers Snyder Research and Extension Farm, Pittstown, NJ.

GASCI CHEAL TAROF AMACH POLPY MOLVE

\section{Cover crop}

Sorghum-sudangrass 64

Sunn hemp

$\begin{array}{ll}64 & 10 \\ 81 & 22\end{array}$

Weed density (plants $\left./ \mathrm{m}^{2}\right)^{\mathrm{z}}$

3

$30 \mathrm{~b}^{\mathrm{y}}$

0.6

$54 \mathrm{~b}$

Weed dry biomass $\left(\mathrm{g} \cdot \mathrm{m}^{-2}\right)$

\begin{tabular}{lllllll} 
Sorghum-sudangrass & $0.4 \mathrm{~b}$ & $0.2 \mathrm{~b}$ & 0.6 & $0.3 \mathrm{~b}$ & 0.1 & 0.5 \\
Sunn hemp & $1.1 \mathrm{a}$ & $0.4 \mathrm{a}$ & 0.5 & $0.9 \mathrm{a}$ & 0.1 & 0.7 \\
\hline
\end{tabular}

${ }^{\mathrm{z}} 1$ plant $/ \mathrm{m}^{2}=0.0929$ plant $/ \mathrm{ft}^{2}, 1 \mathrm{~g} \cdot \mathrm{m}^{-2}=0.0033 \mathrm{oz} / \mathrm{ft}^{2}$.

${ }^{y}$ Data were pooled across years and means within a column followed by different letters are significantly different (Fisher's protected least significant difference test at $P \leq 0.05$ ).

GASCI = hairy galinsoga; CHEAL = common lambsquarters; TAROF $=$ dandelion; $\mathrm{MOLVE}=$ carpetweed; $\mathrm{AMACH}=$ smooth pigweed; POLPY = pennsylvania smartweed. or winter wheat compared with broadleaf species (Adler and Chase, 2007; Skinner et al., 2012). Uddin et al. (2010) showed that large crabgrass and barnyardgrass (Echinochloa crus-galli) growth was significantly less affected by formulated sorgoleone applied preemergence at $200 \mu \mathrm{g} \cdot \mathrm{mL}^{-1}$ than broadleaf species. Thus, sorgoleone, which is considered to be the main compound responsible for the allelopathic activity of various sorghum species (Czarnota et al., 2001; Dayan et al., 2010; Weston et al., 1989), may show reduced inhibitory activity on grassy weeds, especially considering that this compound will be mineralized by soil microorganisms over time.

Cabbage yield. Because of the lack of a significant year-by-treatment effect, cabbage yield was pooled across years. Cabbage yield was unaffected by cover crop species grown the preceding season with an average yield of $51.4 \mathrm{Mg} \cdot \mathrm{ha}^{-1}$ and individual cabbage weight of $1.4 \mathrm{~kg}$ (data not shown). Previous studies investigating the effect of cover crops seeded in spring show that yield of fall-planted cabbage was significantly reduced when the crop was preceded by sorghum-sudangrass (Finney et al., 2009; Kruse, 2015); it was suggested that the allelopathic potential of incorporated sorghum-sudangrass residues may negatively impact cabbage head weight (Finney et al., 2009). The absence of interaction between cabbage yield and sorghum-sudangrass or sunn hemp in the present study may have been caused by the longer period separating the termination of the cover crop from the transplanting if cabbage, allowing some dissipation of the allelopathic effects of sorghum-sudangrass.

However, because of the lack of an appropriate control without preceding cover crop, it is impossible to exclude the hypothesis that both preceding cover crops contributed to decrease cabbage yield. Interestingly, the potential carryover of sorghumsudangrass allelopathy was still noted 10 months after termination on biomass accumulation of hairy galinsoga, common lambsquarters, or smooth pigweed germinating from seeds but had no significant effect on growth of transplanted cabbage.

In conclusion, our findings complement the results of previous studies showing the weed-suppressive activity 
of sorghum-sudangrass cover crop on following cole crops production (Creamer and Baldwin, 2000; Finney et al., 2009; Mennan et al., 2009) and demonstrate that in the case of sorghum-sudangrass, weed suppression activity may still be observed up to 9 months after termination of the cover crops. However, additional measures are needed to achieve season-long weed control, especially for weed species that may be less sensitive to the suppressive activity of sorghum-sudangrass. Despite previous studies demonstrating the allelochemical properties of sunn hemp, sunn hemp residues may not provide sufficiently long activity to impede the emergence and growth of weeds under New Jersey climatic conditions. Overall, $\mathrm{N}$ availability for subsequent fall crop was not improved by growing sunn hemp the previous year which may have been caused by leaching of soil $\mathrm{N}$ in response to the abundant summer precipitations recorded in 2017 and 2018.

\section{Literature cited}

Adler, M.J. and C.A. Chase. 2007. Comparison of the allelopathic potential of leguminous summer cover crops: Cowpea, sunn hemp, and velvetbean. HortScience 42(2):289-293, doi: 10.21273/HORTSCI. 42.2 .289

Bunchek, J., S.B. Mirsky, V.J. Ackroyd, and W.S. Curran. 2018. Cover crops for weed suppression, p. 92-102. In: E. Brown (ed.). Integrated weed management guide for mid-Atlantic grain crops. Northeastern IPM Ctr., Ithaca, NY.

Campiglia, E., R. Mancinelli, E. Radicetti, and F. Caporali. 2010. Effect of cover crops and mulches on weed control and nitrogen fertilization in tomato (Lycopersicon esculentum Mill.). Crop Prot. 29(4): 354-363, doi: 10.1016/j.cropro.2009. 12.001 .

Carmer, S.G., W.E. Nyquist, and W.M. Walker. 1989. Least significant differences for combined analyses of experiments with two- or three-factor treatment designs. Agron. J. 81(4):665-672, doi: 10.2134/ agronj1989.00021962008100040021x.

Chung, I.M. and D.A. Miller. 1995. Allelopathic influence of nine forage grass extracts on germination and seedling growth of alfalfa. Agron. J. 87(4):767-772, doi: 10.2134 /agronj1995.000219620087000 40026x.

Creamer, N.G. and K.R. Baldwin. 2000. An evaluation of summer cover crops for use in vegetable production systems in
North Carolina. HortScience 24(3): 225-233, doi: 10.21273/HORTSCI.35. 4.600 .

Czarnota, M.A., R.N. Paul, F.E. Dayan, C.I. Nimbal, and L.A. Weston. 2001. Mode of action, localization of production, chemical nature, and activity of sorgoleone: A potent PSII inhibitor in Sorghum spp. root exudates. Weed Technol. 15(4):813-825, doi: 10.1614/0890$037 x(2001) 015[0813$ :moalop]2.0.co;2.

Dayan, F.E., A.M. Rimando, Z. Pan, S.R. Baerson, A.L. Gimsing, and S.O. Duke. 2010. Sorgoleone. Phytochemistry 71(10): 1032-1039, doi: 10.1016/j.phytochem. 2010.03.011.

Einhellig, F.A. and J.A. Rasmussen. 1989. Prior cropping with grain sorghum inhibits weeds. J. Chem. Ecol. 15(3):951-960, doi: $10.1007 /$ BF01015190.

Finney, D.M., N.G. Creamer, J.R. Schultheis, M.G. Wagger, and C. Brownie. 2009. Sorghum sudangrass as a summer cover and hay crop for organic fall cabbage production. Renew. Agr. Food Syst. 24(3):225-233, doi: 10.1017/ S174217050999007X.

Griffin, G., W. Jokela, D. Ross, D. Pettinelli, T. Morris, and A. Wilf. 1995. Recommended soil nitrate-N tests, p. 22-29. In: J.T. Sims and A. Wolf (eds.). Recommended soil testing procedures for the northeastern United States. Northeast Reg. Publ. 493. Univ. Delaware, Newark, DE.

Heckman, J.R., T. Morris, J.T. Sims, J.B. Sieczka, U. Krogmann, P. Nitzsche, and R. Ashley. 2002. Pre-sidedress soil nitrate test is effective for fall cabbage. HortScience 37(1):113-117, doi: 10.21273/ HORTSCI.37.1.113.

Héraux, F.M.G., S.G. Hallett, and S.C. Weller. 2005. Combining Trichoderma virens-inoculated compost and a rye cover crop for weed control in transplanted vegetables. Biol. Control 34(1):21-26, doi: $10.1016 / \mathrm{j}$.biocontrol.2005.04.003.

Kim, S.Y., S.K. De Datta, R.P. Robles, K.U. Kim, S.C. Lee, and D.H. Shin. 1994. Allelopathic effect of sorghum extract and residues on selected crops and weeds. Kor. J. Weed Sci. 14(1):34-41.

Kruse, R.A. 2015. Integration of summer and fall cover crops in vegetable cropping systems. MS Diss., Iowa State Univ., Ames, IA, doi: 10.31274/etd-180810-4423.

Kumar, V., D.C. Brainard, and R.R. Bellinder. 2009. Effects of spring-sown cover crops on establishment and growth of hairy galinsoga (Galinsoga ciliata) and four vegetable crops. HortScience 44(3):730-736, doi: 10.21273/HORTSCI.44.3.730.
Linares, J., J. Scholberg, K. Boote, C.A. Chase, J.J. Ferguson, and R. McSorley. 2008. Use of the cover crop weed index to evaluate weed suppression by cover crops in organic citrus orchards. HortScience 43(1):27-34, doi: 10.21273/HORTSCI.43.1.27.

Magdoff, F. 1991. Understanding the Magdoff pre-sidedress nitrate test for corn. J. Prod. Agr. 4(3):297-305, doi: 10.2134/jpa1991.0297.

Mennan, H., M. Ngouajio, E. Kaya, and D. Isik. 2009. Weed management in organically grown kale using alternative cover cropping systems. Weed Technol. 23(1):81-88, doi: 10.1614/WT-08-119.1.

Pilbeam, D.J. and E.A. Bell. 1979. A reappraisal of the free amino acids in seeds of Crotalaria juncea (Leguminosae). Phytochemistry 18(2):320-321, doi: 10.1016/ 0031-9422(79)80081-3.

Price, A.J. and J.K. Norsworthy. 2013. Cover crops for weed management in southern reduced-tillage vegetable cropping systems. Weed Technol. 27(1):212-217, doi: 10.1614/WT-D-12-00056.1.

Putnam, A.R., J. DeFrank, and J.P. Barnes. 1983. Exploitation of allelopathy for weed control in annual and perennial cropping systems. J. Chem. Ecol. 9(8):1001-1010, doi: $10.1007 /$ BF00982207.

Reeves, D.W. 2007. Sunn hemp. p. 193-194. In: A. Clark (ed.). Managing cover crops profitably. Diane Publ., Beltsville, MD.

Skinner, E.M., J.C. Díaz-Pérez, S.C. Phatak, H.H. Schomberg, and W. Vencill. 2012. Allelopathic effects of sunn hemp (Crotalaria juncea L.) on germination of vegetables and weeds. HortScience 47(1):138-142, doi: 10.21273/HORTSCI.47.1.138.

Sweeney, A.E., K.A. Renner, C. Laboski, and A. Davis. 2008. Effect of fertilizer nitrogen on weed emergence and growth. Weed Sci. 56(5):714-721, doi: 10.1614/ WS-07-096.1.

Uddin, M.R., Y.K. Kim, S.U. Park, and J.Y. Pyon. 2009. Herbicidal activity of sorgoleone from grain sorghum root exudates and its contents among sorghum cultivars. Kor. J. Weed Sci. 29(3):229-236.

Uddin, M.R., O.J. Won, and J.Y. Pyon. 2010. Herbicidal effects and crop selectivity of sorgoleone, a sorghum root exudate under greenhouse and field conditions. Kor. J. Weed Sci. 30(4):412-420, doi: 10.5660/KJWS.2010.30.4.412.

U.S. Department of Agriculture, Agricultural Marketing Service. 2016. United states standards for grades of cabbage. 15 Mar. 2021. <https://www.ams.usda. gov/sites/default/files/media/Cabbage Standards.pdf $>$. 
Van Wychem, L. 2019. 2019 survey of the most common and troublesome weeds in broadleaf crops, fruits \& vegetables in the United States and Canada. 30 Nov. 2020. <https://wssa.net/wp-content/uploads/ 2019-Weed-Survey_broadleaf-crops.xlsx $>$.

Wang, G., M. Ngouajio, and D.D. Warncke. 2008. Nutrient cycling, weed suppression, and onion yield following brassica and sorghum sudangrass cover crops. HortTechnology 18(1):68-74, doi: 10.21273/HORTTECH.18.1.68.

Weston, L.A., R. Harmon, and S. Mueller. 1989. Allelopathic potential of sorghum-sudangrass hybrid (sudex). J. Chem. Ecol. 15(6):1855-1865, doi: $10.1007 /$ BF01012272.

Wilson, M.F. and E.A. Bell. 1979. Amino acids and related compounds as inhibitors of lettuce growth. Phytochemistry 18(11): 1883-1884.

Wortman, S.E., J.J. Schmidt, and J.L. Lindquist. 2014. Weed suppressive potential of sudangrass is driven by interactions of root exudates and decomposing shoot residue. Crop Manag. 13(1):1-5, doi: 10.2134/CM-2013-0037-RS. 